Louisiana State University

LSU Digital Commons

$10-1-2014$

\title{
Influence of season and method of topkill on resprouting characteristics and biomass of Quercus nigra saplings from a southeastern U.S. pine-grassland ecosystem
}

\author{
Tracy L. Hmielowski \\ Louisiana State University \\ Kevin M. Robertson \\ Tall Timbers Research Station \\ William J. Platt \\ Louisiana State University
}

Follow this and additional works at: https://digitalcommons.Isu.edu/biosci_pubs

\section{Recommended Citation}

Hmielowski, T., Robertson, K., \& Platt, W. (2014). Influence of season and method of topkill on resprouting characteristics and biomass of Quercus nigra saplings from a southeastern U.S. pine-grassland ecosystem. Plant Ecology, 215 (10), 1221-1231. https://doi.org/10.1007/s11258-014-0380-5 


\title{
Influence of season and method of topkill on resprouting characteristics and biomass of Quercus nigra saplings from a southeastern U.S. pine-grassland ecosystem
}

\author{
Tracy L. Hmielowski • Kevin M. Robertson • \\ William J. Platt
}

Received: 26 February 2014 / Accepted: 29 June 2014 / Published online: 11 July 2014

(C) Springer Science+Business Media Dordrecht 2014

\begin{abstract}
The resprouting ability of woody plants in frequently burned ecosystems may be influenced by the season and method of topkill. We conducted an experiment to test for the effects of season and method of topkill on aboveground biomass, belowground biomass, and mortality of hardwoods found in a southeastern U.S. pine-grassland. We predicted that topkill occurring during the growing season and topkill by fire would have greater negative impacts on resprouting and root growth and result in greater mortality. We conducted a shadehouse experiment in north Florida in which we applied topkill treatments (burn, clip, and no-topkill) in three seasons (dormant, early growing, and mid growing) to Quercus nigra
\end{abstract}

Communicated by S. M. Jacobs.

T. L. Hmielowski $(\bowtie) \cdot$ W. J. Platt

Department of Biological Sciences, Louisiana State

University, 202 Life Sciences Building, Baton Rouge,

LA 70803, USA

e-mail: tracy.hmielowski@gmail.com

Present Address:

T. L. Hmielowski

Tallgrass Prairie and Oak Savanna Fire Science

Consortium, Nelson Institute for Environmental Studies,

University of Wisconsin - Madison, 550 N. Park St.,

70 Science Hall, Madison, WI 53706, USA

K. M. Robertson

Tall Timbers Research Station, 13093 Henry Beadel

Drive, Tallahassee, FL 32312, USA (water oak) saplings. Plants were destructively sampled 12 months post-treatment to measure aboveground and belowground biomass. Saplings topkilled in the early and mid growing seasons had reduced growth and greater mortality one-year post-treatment compared to plants topkilled in the dormant season. While there was no difference in one-year posttreatment biomass or mortality of saplings between the two methods of topkill, clipped plants had more stems and shorter average stem height than plants topkilled by fire. Root growth continued despite topkilling for all seasons and was greatest for no-topkill plants. These results suggest that while topkill reduces biomass, hardwoods have evolved to maintain belowground biomass reserves, enabling genets to resprout following subsequent topkilling and to persist through frequent disturbances.

Keywords Belowground biomass - Aboveground biomass $\cdot$ Prescribed fire $\cdot$ Mechanical topkill

\section{Introduction}

Most woody species in grassland ecosystems resprout following disturbances that kill aboveground plant tissues. When aboveground structures are killed without killing the genetic individual (i.e., topkill), new stems are produced from dormant buds at or below the soil surface by mobilizing energy stored in 
roots (Bowen and Pate 1993; Canadell and LópezSoria 1998; El Omari et al. 2003). The resprouting potential of broadleaf woody plants may be related to the seasonal timing of topkill (Robbins and Myers 1992; Glitzenstein et al. 1995; Grady and Hoffmann 2012), the method by which plants are topkilled, or interactions between the two (Menges and Gordon 2010). Although the response of hardwoods to topkill has been explored, the focus is typically on response of aboveground structures, while less is understood about the effects of topkill on root reserves and growth. Determining how growth rates of both aboveground and belowground tissues of broadleaf woody plants (hereafter hardwoods) respond to differences in timing and method of topkill is important for understanding hardwood demographics and how long-term land management activities can influence the structure of these ecosystems.

In savannas and grasslands, a common topkilling disturbance is frequent fire, which limits the size and number of woody plants on the landscape (Waldrop et al. 1992; Schutz et al. 2009; Werner and Prior 2013). One example of a frequently disturbed savanna is the pine-grassland ecosystems of the southeastern U.S. Historically, hardwoods in southeastern pine-grassland ecosystems were topkilled by frequent fires occurring in the spring and summer months (Platt 1999; Huffman 2006; Stambaugh et al. 2011). Although hardwoods are capable of growing into trees and gaining dominance (Waldrop et al. 1992; Haywood et al. 2001), frequent topkill limits them to the surface vegetation layer (Drewa et al. 2006; Hoffmann et al. 2009; Schutz et al. 2009), where they persist by resprouting. Widespread fire exclusion has resulted in an increase in the hardwood component and reduction herbaceous cover and diversity (Scholes and Archer 1997; Glitzenstein et al. 2012), making control of hardwood resprouts a priority in many conservation plans.

Timing of disturbances can affect resprouting due to seasonal cycles of plant resource allocation and seasonal changes in fire behavior. During the transition from the dormant season to the growing season, hardwoods in temperate ecosystems transfer energy stored in the roots to aboveground structures for growth of new shoots and leaves (Woods et al. 1959). Thus, if topkill occurs during the seasonal low period of belowground resources just after leaf out, the size and number of resprouting stems may be reduced (Glitzenstein et al. 1995; Drewa et al. 2002; Werner and Prior
2013). Fire behavior can have seasonal patterns which may influence resprouting response (Drewa et al. 2002, 2006), but determining these effects can be challenging as changes in plant physiology and fire behavior occur simultaneously. However, there is evidence that greater fireline intensity and duration of heating can result in reduced hardwood resprouting (Malanson and Trabaud 1988; Moreira et al. 2008; Thaxton and Platt 2006). Mortality of hardwoods may also be greater when topkill occurs during the growing season (Glitzenstein et al. 1995; Robertson and Hmielowski 2014), which can further limit the number of hardwoods on the landscape. Although the effect of season of topkill on root growth is not well known, reductions in root growth and associated root storage capacity could have a significant long-term influence on growth of the genetic individual over the course of multiple fire return intervals.

How plants are topkilled may also influence resprouting response. Current land management practices to control the size and number of hardwoods include prescribed fire, mechanical treatments, such as mowing and roller chopping, and herbicide application (Menges and Gordon 2010). Fire, which heats aboveground tissues and the soil surface, may do greater damage to dormant buds at the base of the plant or roots compared to mechanical treatment, increasing the potential for mortality of plants in small size classes and limitations on hardwood recruitment (Hoffmann and Solbrig 2003). Extended heating of tissues to lethal temperatures may reduce the number of resprouting stems and thus overall resprouting biomass (Moreno and Oechel 1991; Bowen and Pate 1993; Kabeya and Sakai 2005; Schutz et al. 2009). Roller chopping and mowing, sometimes used to mimic fire effects, may be more representative of the damage that would be caused by browsing, in that meristems at the base of the plant may remain unaffected. Identifying how method of topkill influences aboveground structure (e.g., number of stems and stem height) and growth rates of genets would predict the potential effects of land management treatments including prescribed burning versus mechanical treatments.

The rate at which genets can recover structures and resources both aboveground and belowground impacts the ability of individuals to persist through frequent disturbances. The ability of woody plants to persist in ecosystems with frequent fire is dependent upon roots 
maintaining sufficient biomass to provide energy for repeated resprouting (Grady and Hoffmann 2012; Robertson and Hmielowski 2014). The resprouting potential of individual plants is at least partially related to the amount of belowground storage at the time of disturbance (Bowen and Pate 1993; Landhäusser and Lieffers 2002), where plants with larger root reserves typically have faster recovery of aboveground biomass (Schutz et al. 2009) or larger resprouts (Kabeya and Sakai 2005). Although some species can fully recover root storage to pre-disturbance levels in as little as two growing seasons as juveniles (Bowen and Pate 1993; Schutz et al. 2009), southeastern pine-grassland oaks may not recover as rapidly and be more susceptible to mortality as juveniles or in smaller size classes (Olson and Platt 1995). Determining the response of root biomass to topkilling is important for understanding how the frequency of disturbance impacts the resprouting response of genets and their persistence in southeastern pine-grassland ecosystems.

The objective of this study was to determine how the season and method of topkill influence net changes in aboveground and belowground biomass of hardwood genets in a southeastern pine-grassland ecosystem. We tested the following three hypotheses. (1) Topkill occurring when root reserves are low during the early growing season will result in a reduced rate of recovery (stem height, number of stems, aboveground biomass), negative impacts on root biomass, and greater genet mortality compared to other seasons of topkill. (2) Fire will result in reduced resprout recovery (number of stems, stem height, biomass) and greater mortality of genets compared to mechanical topkill, because plant tissues and meristems at the base of the plant are exposed to lethal temperatures during fires. (3) Topkill will reduce root biomass or slow root growth because of reduced photosynthesis, and the effect will be greater when topkill occurs in the growing season when root reserves are at a seasonal minimum. We tested these hypotheses by conducting an experiment with even-aged hardwood saplings grown in nursery pots and treated with different methods of topkill at different times of year.

\section{Methods}

The study was conducted on Tall Timbers Research Station and Land Conservancy (TTRS) located north of Tallahassee, Florida $\left(30^{\circ} 35^{\prime} \mathrm{N}, 84^{\circ} 20^{\prime} \mathrm{W}\right)$. This area of north Florida is characterized by average annual low and high temperatures of 13.3 and $26.3{ }^{\circ} \mathrm{C}$, respectively, and annual precipitation of $1,556 \mathrm{~mm}$ (Southeast Regional Climate Center 2013). In this region, leaf flush of deciduous hardwoods typically occurs by March 30 (K. M. Robertson unpublished data), and the growing season is considered to be early March through mid-November (Robbins and Myers 1992; Masters et al. 2007).

We used Quercus nigra (water oak) for the experiment because this species is abundant on TTRS, widespread throughout the southeastern U.S., and may be representative of the resprouting response of other southeastern U.S. hardwoods found in pine-grassland ecosystems (mostly oaks) which also resprout from root crowns (del Tredici 2001; see Drewa et al. 2006). Quercus nigra seedlings that had germinated within the 2008 season were collected from TTRS in August and September of 2008. Plants were initially planted in "cone-tainers" and kept in a shadehouse located on TTRS. In November 2008, surviving seedlings were transferred to 1.0 gal nursery pots filled with a mixture of $50 \%$ topsoil and $50 \%$ sandy clay (soil obtained from Roberts Sand Co. Inc.). In the spring of 2009 and 2011, 6-7 g of fertilizer (Osmocote Brand 18-6-12) was added to each pot to maintain a low level of nutrients to the plants. Pine needles were used to cover the soil surface of each pot to protect against moisture loss and weeds, and we watered and weeded all pots as necessary throughout the experiment to keep soil moist and minimize competition from weeds.

Topkill treatments were applied in 2010 one full growing season after transplanting to nursery pots. Each plant was randomly assigned to one of three seasons of treatment: January (late dormant season), April (early growing season), or July (mid growing season). Within each season, three levels of the topkill treatment (clip, burn, and control [i.e., no-topkill]) were applied to $10-13$ replicate $Q$. nigra saplings for a total of 112 plants (Table 1). Before treatments were applied, all plants were measured for number of stems, height of each stem, and basal diameter of each stem. Basal diameters of the stems were used to calculate the aboveground biomass using an allometric equation for Q. nigra determined at TTRS and a nearby property (Robertson and Ostertag 2009). In addition to the treated plants, we destructively sampled 10-13 plants in each season at the time of topkill to provide a 
Table 1 Number of replicate Quercus nigra plants within each treatment combination of season (dormant, early growing, mid growing) and method (burn, clip, no-topkill) of topkill. The number of plants surviving at each one-year post-treatment date is also shown for each treatment combination

\begin{tabular}{lllc}
\hline Season & $\begin{array}{l}\text { Method of } \\
\text { topkill }\end{array}$ & $\begin{array}{l}\text { Number of } \\
\text { plants treated }\end{array}$ & $\begin{array}{l}\text { Alive 1-year } \\
\text { post-treatment }\end{array}$ \\
\hline Dormant & Burn & 13 & 9 \\
& Clip & 13 & 11 \\
& No-topkill & 13 & 11 \\
Early growing & Burn & 13 & 9 \\
& Clip & 13 & 13 \\
& No-topkill & 12 & 12 \\
Mid growing & Burn & 13 & 6 \\
& Clip & 10 & 5 \\
& No-topkill & 12 & 6 \\
Total & & 112 & 82 \\
\hline
\end{tabular}

measure of baseline belowground biomass for genets at the time of treatment.

Method of topkill treatments for a given season and year was applied on the same day. To apply the clipping treatment, we used hand pruners to clip all stems approximately $2 \mathrm{~cm}$ above the soil surface. Stems were clipped above the soil surface because mechanical treatments typically do not cut stems flush with the ground. We conducted burn treatments within the nursery pots using Pinus palustris (longleaf pine) needles as fuel. Before experimental fires were lit, the pine needle mulch was removed, and foil was placed around the pot edge to protect the plastic from melting. Pine needles for fuel were collected from TTRS and oven dried $\left(24 \mathrm{~h}, 80{ }^{\circ} \mathrm{C}\right)$, then $10.0-11.0 \mathrm{~g}$ of needles (dry biomass) were weighed out, allowed to rehydrate by exposure to ambient air for at least $24 \mathrm{~h}$, and placed on the soil surface within the pot (approximately $231 \mathrm{~cm}^{2}$ ) to be burned. The $10-11 \mathrm{~g}$ of pine needles spread over this area translates to 4.3-4.8 $\mathrm{t} / \mathrm{ha}$, which overlaps with the range of total 1-h fuel loads observed in a nearby old-field southeastern pine forest in north Florida (3.5-4.5 t/ha at 1-2 years since last fire) (Robertson and Ostertag 2007) and is slightly greater than the average fuel load of pine needles measured in open areas of a longleaf pine forest in Louisiana (4.16 t/ha, W. J. Platt unpublished data).

We measured fire characteristics of the experimental burns. Maximum temperatures and flaming residence time (temperatures $>160{ }^{\circ} \mathrm{C}$ ) were recorded by thermocouple wires (K-type $0.125 \mathrm{~mm}$ diameter, one second response time, Omega Engineering Inc.) placed within the bed of pine needles at the base of the stem. Thermocouples were connected to data loggers (Hobo U12-014, Onset Computer Corporation) placed outside of the nursery pot. Any unconsumed fuel was collected from the soil surface following experimental fires, returned to the lab, oven dried, and weighed. Fuel consumption was measured as the difference in dry weights between pre-burn and post-burn fuel. Assuming a standard energy content for longleaf pine needle fuel $(19,647 \mathrm{~kJ} / \mathrm{kg}$ ) (Reid and Robertson 2012), these data were used to calculate the heat released per unit area $\left(\mathrm{kJ} / \mathrm{m}^{2}\right.$ ) (Johnson and Miyanishi 1995) for each experimental fire. We then used heat released per unit area and the flaming residence time to calculated reaction intensity (rate of energy release per unit area; $\mathrm{kW} / \mathrm{m}^{2}$ ) (DeBano et al. 1998). Experimental fires resulted in $100 \%$ topkill.

Final measurements for each season of treatment were made 12 months after the treatment was imposed. Resprouting stems of surviving genets were measured for number, height, and basal diameter. Genets then were destructively sampled by separating them into stems, leaves, and roots. We obtained root biomass by gently washing soil off of the roots. Aboveground tissue and roots were dried in a forced convection drying oven $\left(80^{\circ} \mathrm{C}\right)$ until they reached a constant mass (approx. $96 \mathrm{~h}$ ) at which time they were weighed.

Analysis

We tested for the effects of season and method of topkill on the growth rate of resprouts measured as biomass (aboveground, belowground, and total) 12 months post-treatment (hereafter one-year post-treatment). We used two-way analyses of covariance (ANCOVA), where season of treatment (dormant, early growing, mid growing) and method of topkill (burn, clip, notopkill) were the independent variables serving as main treatments. We used aboveground biomass at the time of topkill as the covariable as it might have a relationship to root biomass and storage capacity and therefore capacity to resprout (Malanson and Trabaud 1988; Kabeya and Sakai 2005; Dacy and Fulbright 2009; Schutz et al. 2009). Analyses were conducted separately for each of the five response variables: aboveground biomass, belowground biomass, total 
biomass, average stem height, and average number of stems (all measured at one-year post-treatment). ANCOVA models were determined for each response variable using PROC GLM SELECT, which aided in the selection of models that would meet the following criteria: (1) the covariate (aboveground biomass of genet at time of treatment) was retained within the final model, and (2) that the hierarchy of the model was maintained when interactions were significant. We used the backward selection method, where potential independent variables were: biomass at time of topkill, season of topkill, method of topkill, and all possible interactions. The level of significance for variables to remain in the model was $\alpha=0.05$. We used the resulting models for each response variable to perform the ANCOVA analysis (SAS PROC MIXED). All statistical analyses were performed using SAS Software V9.3 (SAS Institute, Cary, NC).

We examined the normality of all variables using Shapiro-Wilk tests and histograms in PROC UNIVARIATE. The frequency distributions of aboveground biomass, belowground biomass, and total biomass were improved when natural-log transformed. We used the Kenward-Roger method for calculating the denominator degrees of freedom to account for the differences in the number of replicate genets among treatment combinations, and Tukey-Kramer least-square means tests to perform pairwise comparisons of treatment effects. In these analyses, we used multiple pairwise tests to identify sources of significance when the overall test was significant.

In addition to the ANCOVA analysis, we performed orthogonal contrasts to determine the effect of topkill compared to no-topkill, and clipping compared to burning, within each level of season treatment. Notopkill genets were included with burned and clipped plants in the ANCOVA analysis, even though we would not expect there to be an effect of season of treatment on genets which were not topkilled. Orthogonal contrast statements were constructed to compare topkilled genets (burn and clip) to the no-topkill genets within each level of season (dormant, early growing, and mid growing) for the aboveground biomass, belowground biomass, and total biomass of genets one-year post-treatment. Contrasts were also constructed to compare the two methods of topkill within each level of season for the three one-year posttreatment biomass measurements.
We evaluated the probability of survival to oneyear post-treatment based on season and method of topkill. We used PROC GLIMMIX to evaluate a regression model with a binomial outcome (alive or dead) using the binomial distribution and logit link function options. We reduced the full model with season, method of topkill, estimated biomass at topkill, and all possible interactions to a model that only included season and method of topkill. The reduction was done because the biomass at time of treatment and interactions among treatments were not significant.

To test the third hypothesis, that season and method of topkill will influence root growth, we compared the root biomass of baseline measurements, topkilled plants, and no-topkilled plants. We used a mixed model analysis of variance, with the Kenward-Roger denominator degrees of freedom option due to the unequal number of replicates within treatment combinations (PROC MIXED). We tested for the effect of season (dormant, early growing, mid growing) and method of topkill (baseline, burn, clip, no-topkill), and the interaction of season and method of topkill. These pairwise comparisons were performed using TukeyKramer least-square means tests.

In addition to the analyses to test our three hypotheses, we ran an analysis of variance (ANOVA) to test for differences in observed fire behavior of experimental fires among the three seasons, given that differences in fire behavior may influence resprouting response. We tested for an effect of season of burn treatments on maximum temperature, flaming residence time, heat released per unit area, reaction intensity, and percent fuel consumption.

\section{Results}

Recovery of aboveground biomass and total biomass was lower for genets treated in the early and mid growing season compared to the dormant season. Aboveground biomass one year after treatment application was $52 \%$ lower in the early growing season compared to the dormant season and $64.7 \%$ lower in the mid growing season compared to the dormant season when all genets (including no-topkill) were included in the ANCOVA model (Fig. 1). Similarly, one-year post-treatment total biomass was also reduced for plants treated in the early and mid growing 


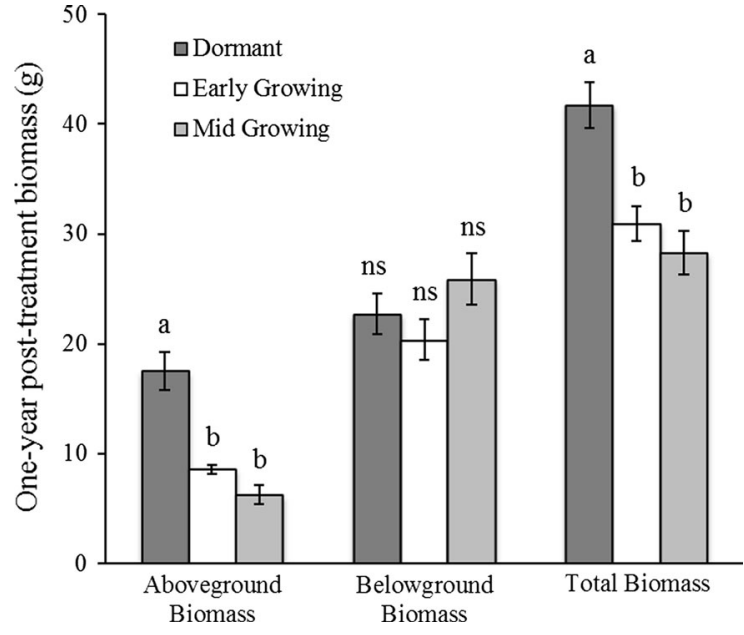

Fig. 1 One-year post-treatment aboveground biomass, belowground biomass, and total biomass for all genets (including notopkill treatment) for each level of season of topkill (dormant, early growing, mid growing). Values are back-transformed least-square means \pm 1 s.e. Different lowercase letters above bars indicate significant differences among seasons for biomass groups, when ' $n s$ ' appears above a bar this indicates treatment variables not included in the ANCOVA model

season compared to the dormant season (Fig. 1). While the effect of season on aboveground and total biomass was significant in the ANCOVA models, there was no difference in belowground biomass among the three seasons (Table 2), which ranged from 20.3 to $25.8 \mathrm{~g}$ (Fig. 1). Aboveground biomass also included one significant interaction between method and season of topkill in the ANCOVA models (Table 2).

Table 2 Effects of the covariate (COV), method of topkill (METHOD), and season of topkill (SEASON), and interactions when included in the ANCOVA model, on 1-year post-treatment aboveground biomass, belowground biomass, and total biomass as indicated by $P$ and $F$ values (degrees of freedom in subscripts)

Bold text indicates $P<0.05$

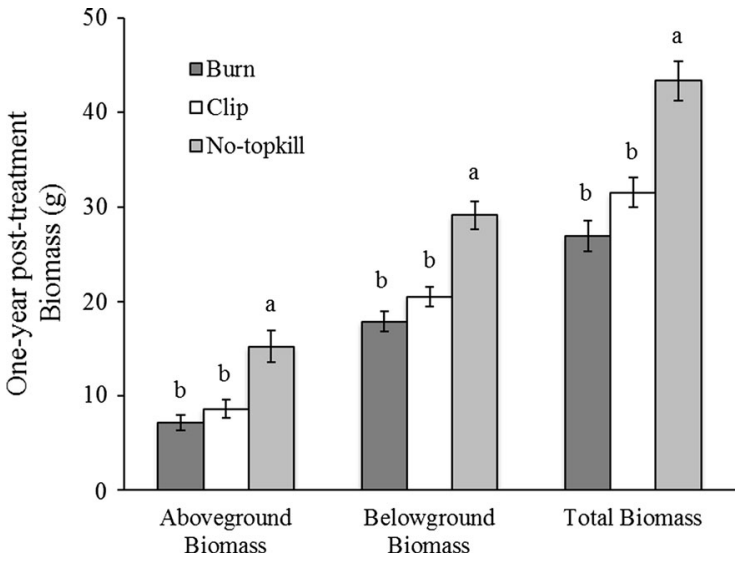

Fig. 2 One-year post-treatment aboveground biomass, belowground biomass, and total biomass for all genets, for each level of method of topkill (burn, clip, and no-topkill). Values are back-transformed least-square means \pm 1 s.e. Different lowercase letters above bars indicate significant differences among topkill treatments for biomass groups

Topkilled plants generally had lower resprout biomass compared to no-topkill plants, but there was not a difference between burning and clipping on posttreatment biomass. One-year post-treatment aboveground biomass, belowground biomass, and total biomass were less for topkilled plants (burn and clip) compared to no-topkill plants (Fig 2). The overall effect of method of topkill was significant in the ANCOVA models (Table 2), but there was not a difference between burn and clip treatments.

\begin{tabular}{|c|c|c|c|c|}
\hline \multirow{10}{*}{$\begin{array}{l}\text { Table } 2 \text { Effects of the } \\
\text { covariate (COV), method of } \\
\text { topkill (METHOD), and } \\
\text { season of topkill } \\
\text { (SEASON), and } \\
\text { interactions when included } \\
\text { in the ANCOVA model, on } \\
\text { 1-year post-treatment } \\
\text { aboveground biomass, } \\
\text { belowground biomass, and } \\
\text { total biomass as indicated } \\
\text { by } P \text { and } F \text { values (degrees } \\
\text { of freedom in subscripts) }\end{array}$} & Dependent variable & Variables in model & $F_{\text {ndf, ddf }}$ & $P$ \\
\hline & \multirow[t]{4}{*}{ Aboveground biomass } & $\mathrm{COV}$ & $3.39_{1,71}$ & 0.069 \\
\hline & & METHOD & $12.73_{2,71}$ & $<0.0001$ \\
\hline & & SEASON & $23.09_{2,71}$ & $<0.0001$ \\
\hline & & METHOD $\times$ SEASON & $4.53_{4,71}$ & 0.0026 \\
\hline & \multirow[t]{2}{*}{ Belowground biomass } & $\mathrm{COV}$ & $115.65_{1,77}$ & $<0.0001$ \\
\hline & & METHOD & $20.20_{2,77}$ & $<0.0001$ \\
\hline & \multirow[t]{3}{*}{ Total biomass } & $\mathrm{COV}$ & $73.67_{1,75}$ & $<0.0001$ \\
\hline & & METHOD & $22.68_{2,75}$ & $<0.0001$ \\
\hline & & SEASON & $14.25_{2,75}$ & $<0.0001$ \\
\hline & \multirow[t]{2}{*}{ Stem number } & $\mathrm{COV}$ & $0.03_{1,78}$ & 0.869 \\
\hline & & METHOD & $43.99_{2,78}$ & $<0.0001$ \\
\hline & \multirow[t]{2}{*}{ Stem height } & $\mathrm{COV}$ & $12.74_{1,78}$ & 0.0006 \\
\hline $\begin{array}{l}\text { Bold text indicates } \\
P<0.05\end{array}$ & & METHOD & $40.02_{2,78}$ & $<0.0001$ \\
\hline
\end{tabular}



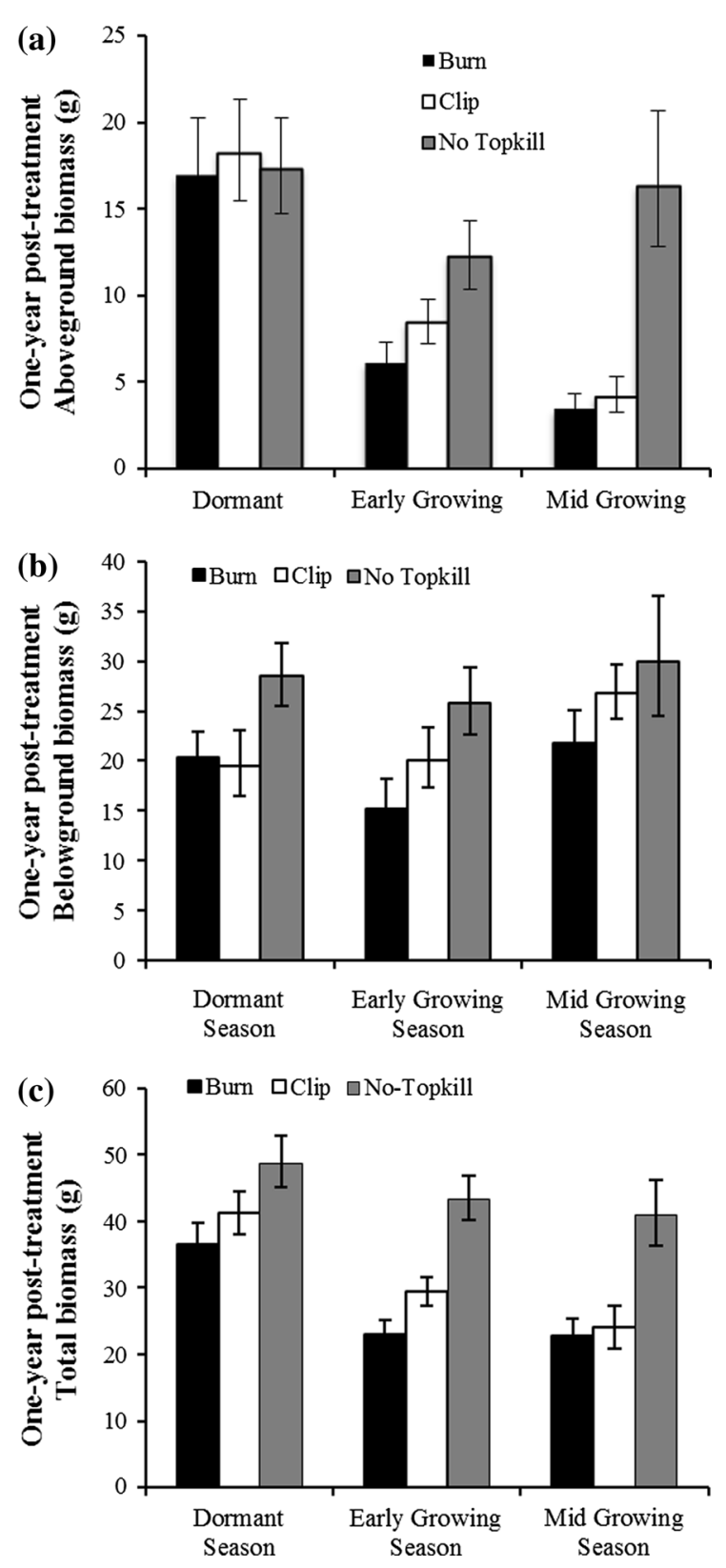

Fig. 3 One-year post-treatment (a) aboveground biomass, (b) belowground biomass, and (c) total biomass for Q. nigra genets in response to method of topkill (burn, clip, and notopkill) and grouped by season of treatment (dormant, early growing, and mid growing). Values are back-transformed leastsquare means \pm 1 s.e.

The orthogonal contrasts indicated that there were differences in biomass associated with topkill compared to no-topkill, but that method of topkill had little effect on post-treatment biomass within each season. In general, one-year post-treatment aboveground, belowground, and total biomass was less for topkilled plants compared to the no-topkill plants (Fig. 3a-c), and the effect was significant (Table 3). However, aboveground biomass in the dormant season was the exception where both topkill and no-topkill plants had a similar post-treatment biomass (Fig. 3a). Clipped and burned plants had similar one-year post-treatment aboveground, belowground, and total biomass across the three seasons (Fig. 3a-c). The only significant difference observed between burned and clipped plants was for total biomass in the early growing season (Table 3), where burned plants had a lower mean biomass than those clipped (Fig. 3c).

Burned and clipped plants had a greater number of stems and reduced stem height compared to no-topkill genets 1-year post-treatment. No-topkill genets typically had a single stem $(1.07 \pm 0.17$ [mean \pm 1 s.e.] $)$, burned plants averaged two stems $(2.08 \pm 0.19)$, and clipped plants had approximately three stems $(3.38 \pm 0.17)$. No-topkill genets were significantly taller $(51.48 \pm 2.51 \mathrm{~cm})$ than topkilled plants, but there was not a significant difference in height between clip $(23.58 \pm 2.51 \mathrm{~cm})$ and burn $(32.35 \pm 2.67 \mathrm{~cm})$ treatments. The overall effect of method of topkill on stem number and stem height was significant in the ANCOVA models (Table 2).

The probability of survival was influenced by season of topkill. One year after treatments were applied, $73 \%$ of the plants (including topkill and notopkill treatments) were alive. The probability of survival was approximately four times greater for plants burned in the dormant season and nine times greater for plants burned in the early growing season compared to those burned in the mid growing season. While the effect of season of burn on survival was significant $(P=0.001)$, there was no effect of method of topkill $(P=0.130)$.

The topkilled genets had less root biomass than those in the no-topkill group one-year post treatment, but they had greater biomass than the baseline root biomass (Fig. 4), suggesting continued growth of roots despite topkilling. The average root biomass of the baseline treatment was approximately $15 \mathrm{~g}$, with a relatively narrow range from 13.67 to $18.56 \mathrm{~g}$, suggesting that all plants had a similar root biomass when topkilled. There was an overall significant difference (Table 4) in belowground biomass among these groups (baseline, burn, clip, and no-topkill), but there was little difference in belowground biomass 
Table 3 Orthogonal contrasts of topkill treatments (burn and clip) compared to no-topkill treatments, and clipping compared to burning, for aboveground biomass, belowground biomass, and total biomass in each season (dormant, early growing, and mid growing)

Significant differences between topkill and notopkill and clipping compared to burning, indicated by $P$ and $F$ values, are highlighted in bold text $(P<0.05)$

\begin{tabular}{|c|c|c|c|c|}
\hline & \multicolumn{2}{|c|}{ Topkill versus no-topkill } & \multicolumn{2}{|c|}{ Clip versus burn } \\
\hline & $F_{\text {ndf, ddf }}$ & $P$ & $F_{\text {ndf, ddf }}$ & $P$ \\
\hline \multicolumn{5}{|l|}{ Aboveground biomass } \\
\hline Dormant season & $0.01_{1,71}$ & 0.9361 & $0.09_{1,71}$ & 0.7594 \\
\hline Early growing season & $7.58_{1,71}$ & 0.0075 & $1.92_{1,71}$ & 0.1699 \\
\hline Mid growing season & $25.54_{1,71}$ & $<0.0001$ & $0.32_{1,71}$ & 0.5743 \\
\hline \multicolumn{5}{|l|}{ Belowground biomass } \\
\hline Dormant season & $12.88_{1,71}$ & 0.0006 & $0.78_{1,71}$ & 0.3799 \\
\hline Early growing season & $22.98_{1,71}$ & $<0.0001$ & $2.50_{1,71}$ & 0.1183 \\
\hline Mid growing season & $4.30_{1}, 71$ & 0.0417 & $0.05_{1,71}$ & 0.8220 \\
\hline \multicolumn{5}{|l|}{ Total biomass } \\
\hline Dormant season & $5.48_{1,71}$ & 0.0221 & $1.06_{1,71}$ & 0.3075 \\
\hline Early growing season & $28.86_{1,71}$ & $<0.0001$ & $4.70_{1,71}$ & $\mathbf{0 . 0 3 3 5}$ \\
\hline Mid growing season & $15.45_{1,71}$ & 0.0002 & $0.13_{1,71}$ & 0.7202 \\
\hline
\end{tabular}

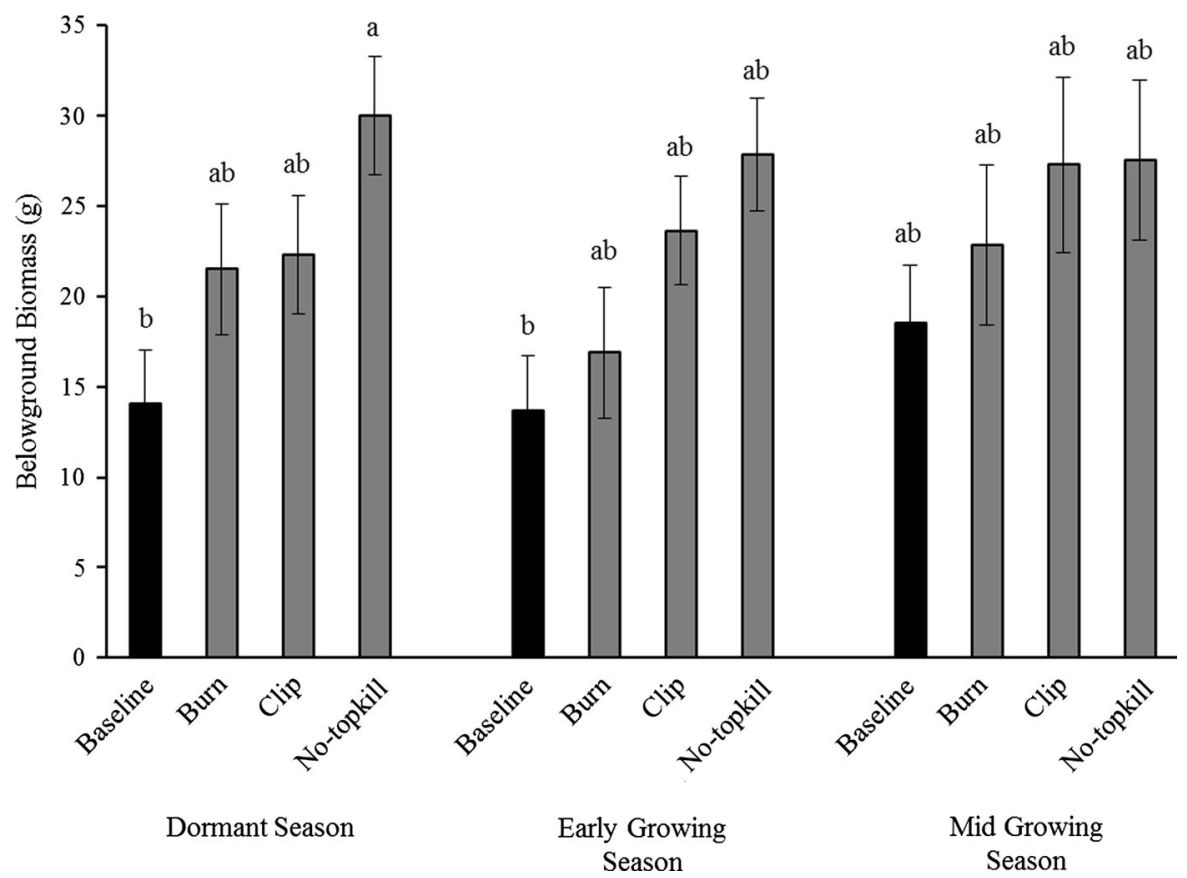

Fig. 4 Belowground biomass of baseline genets destructively sampled at the time of treatment application (black bars) and genets sampled one-year post-treatment (gray bars). Values are back-transformed least-square means \pm 1 s.e. for baseline and

between burned and clipped plants (Fig. 4). There also was not a significant effect of season of topkill on root biomass (Table 4).

Experimental fires were similar among the three seasons. The average maximum flaming temperature across the three seasons was $819{ }^{\circ} \mathrm{C}$ and the flaming all levels of topkill (burn, clip, and no-topkill) within each level of season (dormant, early growing, and mid growing). Different letters above bars indicate significant differences in means across all combinations of season and method of topkill

residence time ranged from 48 to $65 \mathrm{~s}$, with longest residence times in the early growing season (Table 5). Fuel consumption was greater than $90 \%$ in all seasons, and heat release per unit area and reaction intensity did not differ significantly among the three seasons (Table 5). 


\section{Discussion}

Our hypothesis that season of topkill would influence resprouting response was supported with regard to aboveground biomass and total biomass, but not belowground biomass, number of stems, or stem height. The lower one-year post-burn aboveground biomass of resprouting stems topkilled in the early and mid growing season is attributable to topkill occurring when root reserves are at a seasonal low, which is consistent with other studies investigating the effect of season of topkill on resprouting of hardwood species (Waldrop et al. 1992; Glitzenstein et al. 1995; Drewa et al. 2006; Werner and Prior 2013). Our observation that belowground biomass was not impacted by season of topkill, despite an impact on aboveground regrowth, may be the result of plants allocating limited resources toward root maintenance and possibly storage replenishment rather than aboveground growth in the year after topkill occurs (Canadell and López-Soria 1998; Pelc et al. 2011). This allocation of resources to roots rather than aboveground growth may be a trait selected for in ecosystems with frequent unpredictable disturbances (Iwasa and Kubo 1997),

Table 4 Effects of season of topkill (dormant, early growing, and mid growing), method of topkill (clip, burn, no-topkill, and baseline), and treatment interaction on root biomass of $Q$. nigra genets as indicated by $F$ (numerator and denominated degrees of freedom in subscripts) and $P$ values

\begin{tabular}{llr}
\hline & $F_{\text {ndf, ddf }}$ & \multicolumn{1}{r}{$P$} \\
\hline Season & $0.88_{2,108}$ & 0.4161 \\
Method & $8.22_{3,108}$ & $<\mathbf{0 . 0 0 0 1}$ \\
Season $\times$ method & $0.31_{6,108}$ & 0.9281 \\
\hline
\end{tabular}

Bold text indicates $P<0.05$ which is necessary for the persistence of hardwoods in frequently burned ecosystems (Higgins et al. 2007; Schutz et al. 2009; Grady and Hoffmann 2012).

Our observation that burned genets have fewer resprouting stems than clipped genets supports our hypothesis that fire does greater damage to dormant buds. Nevertheless, the equivalent biomass recovery for burned and clipped plants suggests that, while the number of buds capable of resprouting may be reduced by fire, the overall resprouting potential is not limited by the number of surviving buds. This increased number of stems observed with clipping may be a short term response as multi-stemmed genets have been observed to self-thin as the time since disturbance increases (Brown 1994; Gardiner and Helming 1997).

Although mortality did not differ among methods of topkill, greater mortality in the mid growing season may indicate that topkill when root resources are limited can increase the likelihood of death. This supports the idea that greater mortality associated with frequent growing season burns leads to a reduction in the number of hardwood genets over time (Waldrop et al. 1992; Herman 1995; Glitzenstein et al. 2012). Nevertheless, we recognize that the increased mortality associated with topkill in the mid growing season may be attributable to genets being stressed from being potted, reflected in the greater mortality of notopkill genets in addition to those burned and clipped.

The limited root growth of topkilled plants supported our third hypothesis. The greatest gains in root biomass were for no-topkill genets, demonstrating that one effect of topkill is to reduce the rate of root growth (Chiatante et al. 2005, 2006). When fires are frequent, this slowing of root growth may limit the potential for individuals to resprout and achieve sizes that are less

Table 5 Fire characteristics (maximum temperature, flaming residence time, heat released per unit area, reaction intensity, and percent fuel consumed) observed for each season (dormant, early growing, and mid growing)

\begin{tabular}{|c|c|c|c|c|c|}
\hline & Dormant & Early growing & Mid growing & $F_{\mathrm{df}}$ & $P$ \\
\hline Maximum temperature $\left({ }^{\circ} \mathrm{C}\right)$ & $788 \pm 225$ & $878 \pm 153$ & $792 \pm 217$ & $0.83_{2}$ & 0.441 \\
\hline Flaming residence time $(\mathrm{s})$ & $48 \pm 17$ & $65 \pm 16$ & $49 \pm 22$ & $9.48_{2}$ & 0.031 \\
\hline Heat per unit area $\left(\mathrm{kJ} / \mathrm{m}^{2}\right)$ & $88,657 \pm 2,664$ & $81,990 \pm 3871$ & $82,605 \pm 4,648$ & $0.004_{2}$ & 0.996 \\
\hline Reaction intensity $\left(\mathrm{kW} / \mathrm{m}^{2}\right)$ & $2,025 \pm 782$ & $1,305 \pm 458$ & $3,759 \pm 7176$ & $0.25_{2}$ & 0.775 \\
\hline Percent fuel consumed & $97.79 \pm 2.86$ & $90.95 \pm 4.23$ & $90.92 \pm 4.06$ & $0.31_{2}$ & 0.734 \\
\hline
\end{tabular}

Values are mean \pm 1 s.d.

Significant effects of season, indicated by $P$ and $F$ values, are highlighted in bold text $(P<0.05)$ 
susceptible to topkill in subsequent fires (Schutz et al. 2009; Werner and Prior 2013). Although we did not directly measure root reserves, belowground biomass of topkilled plants was equal to or greater than the baseline biomass, suggesting that frequent topkill does not reduce the allocation of resources to the roots to the point of preventing maintenance and net growth, even in small size classes (Grady and Hoffmann 2012; Robertson and Hmielowski 2014).

The observed seasonal differences in resprouting response cannot be attributed to differences in fire behavior in this experiment. Fire characteristics were similar for all three seasons, which was expected given that fuel preparations were identical for all genets. Given that there was no indication that fire severity varied across seasons in this experiment, and clipped plants responded similarly across seasons, we attributed seasonal differences in biomass to changes in resource allocation. However, the results of this experiment do not preclude the potential for seasonal effects of fire behavior in nature.

Results of this study suggest hardwoods have a life history strategy in which maintaining belowground biomass takes priority over aboveground growth. While topkill reduces aboveground biomass and the potential for genets to grow into full-sized trees, the sustained root biomass and high genet survival are traits that enable hardwoods to persist in frequently disturbed grasslands (Grady and Hoffmann 2012; Werner and Prior 2013). Additionally, our results show that root biomass of topkilled plants actually increased one year following fire, emphasizing the high priority of resource allocation toward maintaining root reserves over aboveground growth. Recent work has demonstrated that, while hardwood genets with large amounts of aboveground biomass tend to produce large resprouts, there is a point (i.e., equilibrium size) above which aboveground biomass is unlikely to be fully recovered to pre-burn levels (Hoffmann and Solbrig 2003; Grady and Hoffmann 2012; Robertson and Hmielowski 2014), suggesting that these results would be similar for surviving genets over multiple burns. Given the greater reduction in overall biomass of genets topkilled in the early and mid growing season, management approaches to reduced competition from hardwoods should consider seasonal timing when planning management activities to maintain the overall structure of southeastern pinegrassland ecosystems.
Acknowledgments We would like to thank Tall Timbers Research Station and Land Conservancy for providing shadehouse space and supplies for this experiment, Josh Picott, Angie Reid, Jason Isbell, and Kristin Politano for assistance potting, watering, weeding, and sampling the experiment, and Matt Slocum and James Geaghan for advice on statistical analyses. Matt Slocum, Bret Elderd, Philip Stouffer, and two anonymous reviewers provided insightful comments which improved the manuscript. This project was funded by Tall Timbers Research Station and grants from Gene Phipps and LSU Biograds.

\section{References}

Bowen BJ, Pate JS (1993) The significance of root starch in postfire shoot recovery of the resprouter Stirlingia latifolia R. Br. (Proteaceae). Ann Bot 72:7-16

Brown D (1994) The development of woody vegetation in the first 6 years following clear-cutting of a hardwood forest for a utility right-of-way. For Ecol Manag 65:171-181

Canadell J, López-Soria L (1998) Lignotuber reserves support regrowth following clipping of two mediterranean shrubs. Func Ecol 12:31-38

Chiatante D, Iorio AD, Scippa GS (2005) Root responses of Quercus ilex L. seedlings to drought and fire. Plant Biosyst 139:198-208

Chiatante D, Iorio AD, Sciandra S, Scippa GS, Mazzoleni S (2006) Effect of drought and fire on root development in Quercus pubescens Willd. and Fraxinus ornus L. seedlings. Environ Exp Bot 56:190-197

Dacy EC, Fulbright TE (2009) Survival of sprouting shrubs following summer fire: effects of morphological and spatial characteristics. Rangel Ecol Manag 62:179-185

DeBano LF, Neary DG, Ffolliott PF (1998) Fire's effects on ecosystems. Wiley, New York

del Tredici P (2001) Sprouting in temperate trees: a morphological and ecological review. Bot Rev 67:121-140

Drewa PB, Platt WJ, Moser EB (2002) Fire effects on resprouting of shrubs in headwaters of southeastern longleaf pine savannas. Ecology 83:755-767

Drewa PB, Thaxton JM, Platt WJ (2006) Response of rootcrown bearing shrubs to differences in fire regimes in Pinus palustris (longleaf pine) savannas: exploring old-growth questions in second-growth systems. Appl Veg Sci 9:27-36

El Omari B, Aranda X, Verdaguer D, Pascual G, Fleck WE (2003) Resource mobilization in Quercus ilex L. resprouts. Plant Soil 252:349-357

Gardiner ES, Helming LM (1997) Development of water oak stump sprouts under a partial overstory. New For 14:55-62

Glitzenstein JS, Platt WJ, Streng DR (1995) Effects of fire regime and habitat on tree dynamics in north Florida longleaf pine savannas. Ecol Monogr 65:441-476

Glitzenstein JS, Streng DR, Masters RE, Robertson KM, Herman SM (2012) Fire-frequency effects on vegetation in north Florida pinelands: another look at the long-term Stoddard fire research plots at Tall Timbers Research Station. For Ecol Manag 264:197-209

Grady JM, Hoffmann WA (2012) Caught in a fire trap: recurring fire creates stable size equilibria in woody resprouters. Ecology 93:2052-2060 
Haywood JD, Harris FL, Grelen HE, Pearson HA (2001) Vegetative response to 37 years of seasonal burning on a Louisiana longleaf pine site. South J Appl For 25:122-130

Hermann SM (1995) Stoddard fire plots: lessons for land management thirty-five years later. Tall Timbers Spring Game Bird Seminar, Tall Timbers Research Station, Tallahassee

Higgins SI, Bond WJ, February EC, Bronn A, Euston-Brown DIW, Enslin B, Govender N, Rademan L, O'Regan S, Potgieter ALF, Scheiter S, Sowry R, Trollope L, Trollope WSW (2007) Effects of four decades of fire manipulation on woody vegetation structure in savanna. Ecology 88:1119-1125

Hoffmann WA, Solbrig OT (2003) The role of topkill in the differential response of savanna woody species to fire. For Ecol Manag 180:273-286

Hoffmann WA, Adasme R, Haridasan M, Carvalho MTD, Geiger EL, Pereira MAB, Gotsch SG, Franco AC (2009) Tree topkill, not mortality, governs the dynamics of savanna-forest boundaries under frequent fire in central Brazil. Ecology 90:1326-1337

Huffman JM (2006) Historical fire regimes in southesern pine savannas. Dissertation, Louisiana State University, Baton Rouge

Iwasa Y, Kubo T (1997) Optimal size of storage for recovery after unpredictable disturbances. Evol Ecol 11:41-65

Johnson EA, Miyanishi K (1995) The need for consideration of fire behavior and effects in prescribed burning. Restor Ecol 3:271-278

Kabeya K, Sakai S (2005) The relative importance of carbohydrate and nitrogen for the resprout ability of Quercus crispula seedlings. Ann Bot 96:479-488

Landhäusser SM, Lieffers VJ (2002) Leaf area renewal, root retention and carbohydrate reserves in a clonal tree species following above-ground disturbance. J Ecol 90:658-665

Malanson GP, Trabaud L (1988) Vigour of post-fire resprouting by Quercus coccifera L. J Ecol 76:351-365

Masters RE, Robertson KM, Palmer B, Cox J, McGorty K, Green L, Ambrose CA (2007) Red Hills forestry stewardship guide. Tall Timbers Miscellaneous Publication No. 12. Tall Timbers Research Station Inc., Tallahassee

Menges ES, Gordon DR (2010) Should mechanical treatments and herbicides be used as fire surrogates to manage Florida's uplands? A review. Florida Sci 73:147-174

Moreira F, Catry F, Duarte I, Acácio B, Sande Silva J (2008) A conceptual model of sprouting responses in relation to fire damage: an example with cork oak (Quercus suber L.) trees in Southern Portugal. Plant Ecol 201:77-85

Moreno JM, Oechel WC (1991) Fire intensity and herbivory effects on postfire resprouting of Adenostoma fasciculatum in Southern California Chaparral. Oecologia 85:429-433

Olson MS, Platt WJ (1995) Effects of habitat and growing season fires on resprouting of shrubs in longleaf pine savannas. Vegetacio 119:101-118
Pelc BD, Montgomery RA, Reich PB (2011) Frequency and timing of stem removal influence Corylus americana resprout vigor in oak savanna. For Ecol Manag 261:136-142

Platt WJ (1999) Southeastern pine savannas. In: Anderson RC, Fralish JS, Baskin JM (eds) Savannas, barrens, and rock outcrop plant communities of North America. Cambridge University Press, Cambridge, pp 23-51

Reid AM, Robertson KM (2012) Energy content of common fuels in upland pine savannas of the south-eastern U.S. and their application to fire behaviour modeling. Int J Wildland Fire 21:591-595

Robbins LE, Myers RL (1992) Seasonal effects of prescribed burning in Florida: a review. Miscellaneous Publication No. 8, Tall Timbers Research, Inc., Tallahassee

Robertson KM, Hmielowski TL (2014) Effects of fire frequency and season on resprouting of woody plants in southeastern U.S. pine-grassland communities. Oecologia 174:765-776

Robertson KM, Ostertag TE (2007) Effects of land use on fuel characteristics and fire behavior in pinelands of southwest Georgia. In: Proceedings of the 23rd tall timbers fire ecology conference: fire in grassland and shrubland ecosystems. Tall Timbers Research Station, Tallahassee, pp 181-191

Robertson KM, Ostertag TE (2009) Biomass equations for hardwood resprouts in fire-maintained pinelands in the southeastern United States. South J Appl For 33:121-128

Scholes RJ, Archer SR (1997) Tree-grass interactions in savannas. Annu Rev Ecol Syst 28:517-544

Schutz AEN, Bond WJ, Cramer MD (2009) Juggling carbon: allocation patterns of a dominant tree in a fire-prone savanna. Oecologia 160:235-246

Southeast Regional Climate Center (2013) Historical climate summaries. http://www.sercc.com/climateinfo/historical/ historical.html. Accessed 19 April 2013

Stambaugh MC, Guyette RP, Marschall JM (2011) Longleaf pine (Pinus palustris Mill.) fire scars reveal new details of a frequent fire regime. J Veg Sci 22:1094-1104

Thaxton JM, Platt WJ (2006) Small-scale fuel variation alters fire intensity and shrub abundance in a pine savanna. Ecology 87:1331-1337

Waldrop TA, White DL, Jones SM (1992) Fire regimes for pinegrassland communities in the Southeastern United States. For Ecol Manag 47:195-210

Werner PA, Prior LD (2013) Demography and growth of subadult savanna trees: interactions of life history, size, fire season, and grassy understory. Ecol Monogr 83:67-93

Woods FW, Harris HC, Caldwell RE (1959) Monthly variations of carbohydrates and nitrogen in roots of sandhill oaks and wiregrass. Ecology 40:292-295 